\title{
Regional Development in Croatia from the turn of Millennium to the EU accession*
}

\begin{abstract}
Researching territorial development in the independent Croatia is an interesting subject for research from many aspects. Unique developments - state formation, war, spatial restructuring of population - have been taking place up until the turn of the millennium, which have also been accompanied by several significant regional impacts. The historical differences have been escalated by the time of transition, the process of Euro-Atlantic integration, and eventually, by the world economic crisis. This study takes into account the most important spatial forming factors and developments on a county level, focusing on the time frame, at the end of which Croatia became a full member of the European Union.
\end{abstract}

Keywords: Croatia, regions, territorial inequalities, demography, urban network.

\section{Introduction}

Despite its relatively small territory, Croatia is composed of regions, which can be characterized by striking differences (Klemenčić 1994). This is mainly due to the country's unique geographic location and the particular shape of the state's territory. The area of the country integrates regions, whose relations are different in many aspects and which partly overlap. The natural, social, historical factors' space forming effect is rather strong; however, there is no one determining spatial shaping force. Research on regionalization and spatial subdivision carried out from the 1950s has not resulted in full compromise (because the borders of macroregions cannot be delimitated by lines), however, the acceptance of delineations synthesized by Josip Roglič (1955) and Veljko Rogič $(1962,1973,1983)$ is relatively high, thus, they have been incorporated in both research and education, and consequently are publicly acknowledged (Vresk 1995, Magaš 2003, Pavić 2008). The country is composed of three main (topographical) units: the Pannonian and Adriatic regions and the Dinaric region separating them. All three macro regions can be further subcategorized (Magaš 2011). Croatia's shape is rather specific; it is very different from the compact state shape concept established by politic geography. The country not only has a long coastline, but it is also rich in rivers. River Sava forms an internal axis and is a border river, while the Danube and Drava are border rivers of great importance.

a) Institute for Regional Studies, Centre for Economic and Regional Studies of the Hungarian Academy of Sciences, H-7621 Pécs, Papnövelde u. 22,. Hungary. E-mail: szracz@rkk.hu

* Research for this publication has been supported under OTKA Hungarian Scientific Research Fund grant \#NK 104985 (New driving forces of spatial restructuring and regional development paths in Eastern Europe at the beginning of 21st century). 


\section{Territorial administration, statistical regions}

The new system of territorial administration was established by the 1992 Law on Local governments: when creating the independent Croatian government, they returned to the historic system of counties from the era before 1918. Based on this, the territory of Croatia is organized in counties (županija), towns/cities (grad) and municipalities (općina), with the latter two forming the statistical subcategory of settlements. The counties, besides being the middle level of the local government system, also act as territorial representatives of the state administration. Mainly historical, transport and economic spatial links prevailed throughout the process of delineations. County borders have been modified only to a minimal extent over the last two decades. The basic units of the local government system are cities and towns. At the time of the 2011 census, the country was organized into 6,756 settlements, from which there were 127 towns/cities (including the capital city) and 429 municipalities. The number of counties was 21 (including Zagreb, a city with county rights).

Counties, county seats and regions in Croatia, 2013

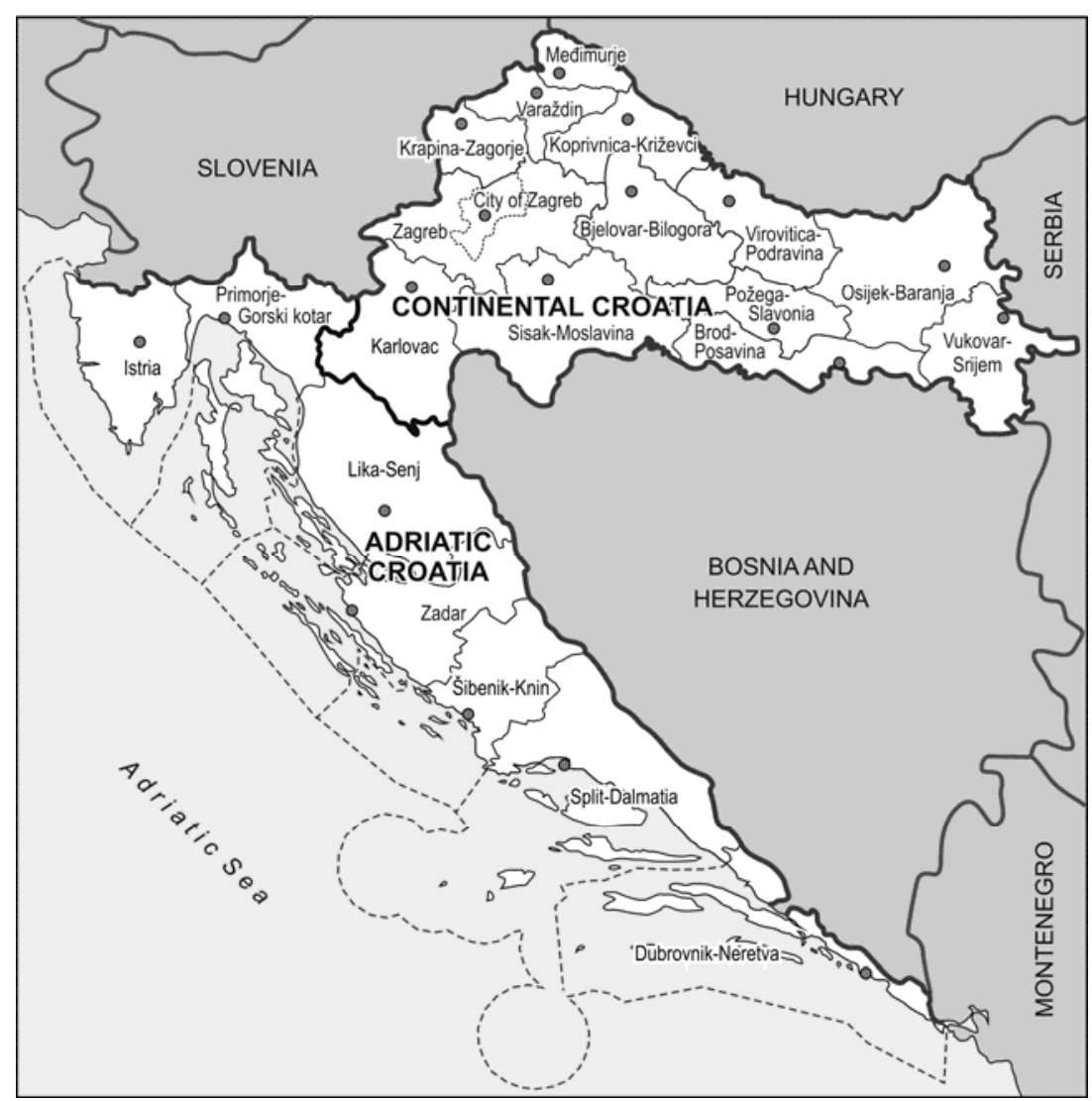

Source: author's compilation. 
Considering the European spatial categories, there is no NUTS2 local government level in Croatia; NUTS3 is the level of counties, while LAU2 can be identified with the level of local governments (cities and towns). The question of NUTS2 units, which can be considered the most important from the viewpoint of EU resources, was a debate until the EU accession. Following much discussion (five, four, three and two region models), three NUTS2 regions were delineated in 2007: Adriatic region, Pannonian region and Central Croatia. Thus, due to the rather underdeveloped Slavonian territories, the region of the capital city - as well as the whole country - can receive higher EU funds in the 2014-2020 programming period. This dual categorization can also be considered adequate from a geographic-functional viewpoint (Figure 1).

\section{Demographic trends}

The spatial structure of Croatia's population is very heterogeneous due to the extremely diverse topography. Demographic differences have increased since the end of WW II, and this trend is a result of several factors besides the changes in its population retaining ability. Although the developments leading to significant population flows ended in the $20^{\text {th }}$ century, several trends - e.g. loss of the rural population, migration towards large city regions - carried on. Despite all these, the high number of small settlements has remained a specificity of the Croatian settlement network.

The population's territorial structure is reviewed in a county dimension since the regional values cover significant internal differences. At the time of the 2011 census, the counties of large cities were the most populous (the region of the capital city had 1.1million inhabitants, the population of Split's county was 455 thousand, while the counties of Osijek and Rijeka had respectively 300 thousand inhabitants each). The average population of the other counties was 133 thousand, and in the least populated mountain regions, this number was 51 thousand. Population density on a national average was 75.71 , this is $65 \%$ of the EU27; mainly the geographical segmentation and the topographical conditions limiting the population retaining ability are responsible for this phenomenon (Figure 2).

The population of Croatia had been increasing until the time of the Balkan conflict (the increase rate was 3.96\% between 1971 and 1981 and 3.97\% between 1981 and 1991). However, demographic trends changed throughout the decade of war, and due to the significant population flows there was a substantial population decline $(6.11 \%)$ between 1991 and 2001. The loss of population continued on into the new millennium: in the 2001-2011 period, Croatia's population declined by $2.67 \%$ (the census definition of population changed in 2001).

The traditional migration trends (towards the capital and coastline) were augmented after the turn of the millennium. The population of the Adriatic region decreased by $1.1 \%$ $(15,073$ people) while the losses of the continental area reached $10 \%$ (124,417 people). The population of Zagreb (10,872 people, 1.4\%), Zagreb county, Istria and Zadar (7,972 people, $4.9 \%$ ) increased. In the littoral counties, the pace of population loss was lower than the national average. The loss was above $10 \%$ in Vukovar, Slavonski Brod and Bjelovar. The population loss of Osijek and Vukovar counties combined was more than 50 thousand. Regarding the past four census rounds, only three counties (the city and 
county of Zagreb and Istria county) have maintained their positive population change balance, while in seven counties (Krapina surrounding the capital city, Koprivnica, Bjelovar, Sisak, Karlovac, Lika and Virovitica) there have been only negative values (DZS 2001, 2011a, 2013a).

Population density (people/ $\mathrm{km}^{2}$ ) and population (thousand people) in the counties, 2011

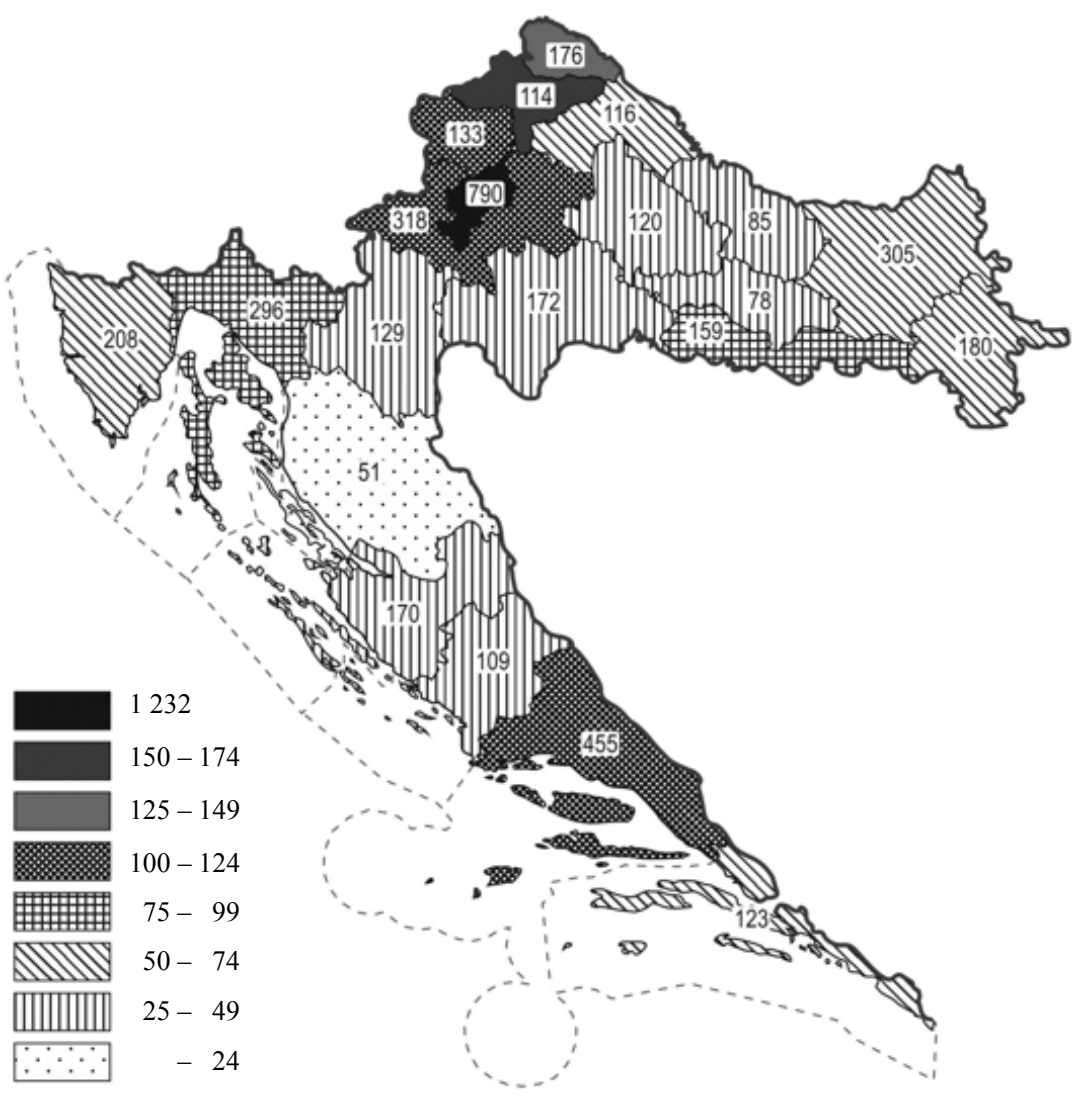

Source: author's compilation based on census data.

Life expectancy at birth has been increasing in Croatia since the Second World War. At the same time, the proportion of seniors has been growing at the expense of the younger generations (the proportion of people of working age has been relatively steady). Therefore, the average age of the population has been increasing, and in a European context, it is one of the highest. The national aging index is $115 \%$; its disadvantageous social, economic and budget consequences are well known. Dependency shows an advantageous picture in comparison to the European average. The county rankings of average age and aging show a similar picture, which might be translated into trend-like developments and long-term consequences (in the counties with higher average age the ageing index is also higher). 
Life expectancy at birth for males in the Adriatic region is two years higher than in the continental part of the country, for females, the difference is somewhat lower. Based on the thirty years foresight, this difference will keep on increasing in case of males: in contrast to the Adriatic territories, Central Croatia will lag behind by 2 years, and Slavonia by 3 years; for females, the gap will be less: 1 and 2 years respectively. Considering the internal differences of macro-regional statistics, in the Adriatic region Lika, and the capital city show significant divergence. The longest life expectancy, 2.5 years higher than the Croatian average both for men and women, can be expected in Dubrovnik county. The county with the lowest life expectancy for boys is Krapina (average -3.8 years) and for girls it is Bjelovar county (average -1.93) (DZS 2011b).

Population changes are determined by reproduction and migration. Throughout the last decade, the number of births was between 40 and 45 thousand, while mortality fluctuated (steadily since 1980) between 50 and 55 thousand. The number of deaths has persistently exceeded the number of live births since 1998; which phenomenon has caused the drastic drop in the birth figures (this trend has been continuous since the late 1970s), and has resulted in an aging population and natural population decline. Table 1 shows the county level data of the natural population decline. Only three counties have a positive balance: Split, Dubrovnik and Međimurje županija. In the case of Zadar and the capital city, there were years with a positive figure. The decline in the counties of Zagreb, Istria, Slavonski Brod and Vukovar was lower than the national average. The natural loss was highest in the ring around the capital city region (Krapina, Koprivnica, Bjelovar, Sisak and Karlovac) and the mountains. Migration balance mainly worked in the same direction as natural productivity (Table 1).

Natural productivity (per thousand people) in Croatian counties, 2001-2011

\begin{tabular}{|c|c|c|c|c|c|c|c|c|c|c|c|}
\hline County & 2001 & 2002 & 2003 & 2004 & 2005 & 2006 & 2007 & 2008 & 2009 & 2010 & 2011 \\
\hline$\overline{\text { Bjelovar-Bilogora }}$ & -4.8 & -5.3 & -6.3 & -5.5 & -4.8 & -4.8 & -5.5 & -5.0 & -5.5 & -4.6 & -5.5 \\
\hline Slavonski Brod-Posavina & -0.6 & -2.0 & -2.1 & -2.2 & -1.3 & -1.5 & -2.1 & -1.9 & -1.3 & -2.8 & -2.2 \\
\hline Dubrovnik-Neretva & 0.8 & -0.3 & -1.3 & 0.4 & -0.0 & 1.0 & 0.6 & 1.1 & 1.1 & 1.1 & -0.1 \\
\hline Osijek-Baranja & -1.8 & -2.4 & -3.8 & -2.8 & -2.8 & -3.1 & -3.9 & -3.1 & -2.8 & -3.8 & -3.5 \\
\hline Istria & -2.7 & -2.5 & -3.2 & -2.0 & -2.1 & -1.7 & -1.5 & -0.7 & -1.4 & -2.0 & -1.9 \\
\hline Koprivnica-Križevci & -4.1 & -4.5 & -4.9 & -5.2 & -3.7 & -4.7 & -4.6 & -4.3 & -4.4 & -4.2 & -4.3 \\
\hline Karlovac & -6.7 & -6.9 & -7.7 & -7.7 & -7.4 & -6.4 & -6.7 & -6.6 & -7.1 & -6.6 & -7.7 \\
\hline Krapina-Zagorje & -5.8 & -5.3 & -6.5 & -5.4 & -4.9 & -5.1 & -5.2 & -5.2 & -5.2 & -4.8 & -5.2 \\
\hline Lika-Senj & -7.8 & -7.9 & -8.1 & -7.3 & -7.6 & -8.9 & -9.6 & -9.9 & -7.8 & -8.5 & -8.8 \\
\hline Međi & 0.9 & -0.6 & -0.2 & -0.3 & -0.2 & -0.6 & -0.1 & 0.1 & 0.4 & 0.4 & -0.0 \\
\hline Požega-Slavonia & -1.6 & -1.8 & -2.2 & -2.7 & -1.8 & -3.0 & -3.3 & -2.2 & -3.4 & -3.7 & -4.5 \\
\hline Šibenik-Knin & -2.5 & -3.8 & -4.8 & -4.6 & -4.7 & -5.0 & -4.6 & -4.1 & -4.2 & -4.7 & -4.6 \\
\hline almatia & 0.9 & 1.2 & 0.0 & 1.6 & 0.9 & 1.2 & 0.8 & 0.4 & 0.5 & 0.8 & -0.2 \\
\hline Sisak-Moslavina & -4.7 & -5.6 & -6.0 & -5.6 & -5.7 & -5.8 & -6.8 & -5.8 & -5.6 & -6.2 & -6.3 \\
\hline Primorje-Gorski kot & -3.4 & -3.8 & -4.0 & -2.9 & -3.5 & -3.2 & -3.7 & -3.0 & -2.7 & -3.3 & -3.4 \\
\hline Varaždin & -2.6 & -3.5 & -4.4 & -2.8 & -2.0 & -2.0 & -3.3 & -3.5 & -2.8 & -3.1 & -3.4 \\
\hline Virovitica-P & -3.8 & -4.0 & -4.7 & -4.1 & -3.9 & -4.3 & -4.7 & -4.7 & -4.3 & -4.5 & -5.1 \\
\hline Vukovar-Srijem & -0.3 & -1.5 & -1.7 & -1.0 & -1.4 & -1.5 & -1.8 & -1.7 & -2.0 & -2.7 & -3.2 \\
\hline Zadar & 1.0 & -0.4 & -1.2 & -0.3 & 0.5 & 0.2 & -0.7 & 0.0 & -0.2 & 0.1 & -0.2 \\
\hline Zagreb & -1.6 & -1.8 & -1.7 & -1.3 & -1.2 & -0.7 & -0.8 & -0.3 & -0.3 & -0.5 & -0.2 \\
\hline City of Zagreb & -1.3 & -1.5 & -1.6 & -0.9 & -1.1 & -0.8 & -0.9 & 0.0 & 0.4 & 0.4 & 0.0 \\
\hline $\mathrm{Cr}$ & -1.9 & -2.4 & -2.9 & -2.1 & -2.1 & -2.0 & -2.4 & -1.9 & -1.8 & -2.0 & -2.3 \\
\hline
\end{tabular}

Source: author's calculation based on the data of the Croatian Bureau of Statistics. 
From the aspect of net migration, three regions can be clearly separated: the coastal areas and the capital city can be characterized by immigration; in the mountains long term migration can be seen. In Slavonia, as well as the Northern counties - Međimurje županija, Varaždin, Krapina, Koprivnica - migration plays an insignificant role in population changes. Between 2002 and 2011, the population of the capital city and Zagreb county increased by 20 thousand. The counties of Zadar, Split and Istria, had a positive balance above 10 thousand people. The population in the other three coastal counties increased by 2.6-7 thousand people. The population of Varaždin ( +167 people) and Krapina ( -85 people) was not substantially affected by migration. Međimurje županija and Koprivnica suffered a slight loss of 700 people. In the mountains, long characterized by emigration, 1,237 people left Lika. The migration output was more significant in the Slavonian counties (3-5 thousand people), while more than 8 thousand people left the counties of Vukovar and Sisak. Considering the indicators per thousand people in the 2002-2011 time frame, net migration was positive in the capital city region and the Adriatic counties: 2.2-6.6 on an average (the 8.4 average of Zadar county was outstanding). Migration slightly affected Varaždin and Krapina counties; however, the population loss in the other two Northern counties did not exceed 0.6 . The -1.5 value of Osijek county was the best in Slavonia. The mountain areas and the other Pannonian counties suffered more significant losses: 2.3-5.0 per thousand annually on an average. Until 2003, it was Zagreb county, then the region of Zadar that attracted the most migrants. Šibenik (16.3) and Lika (13.3) showd the highest values when considering the differences between the single years.

When studying the internal structure of migration, it is necessary to explore both international and national migration (Mežnarić-Stubbs 2012). Immigrants from abroad chose the two large cities (Zagreb and Split), adding respectively 14 and 11 thousand people to the population. The coastal areas and the capital city agglomeration have been the traditional targets of international immigrants. From among the Slavonian counties, it was only Slavonski Brod that had a net positive balance, which was presumably due to immigration from the Southern neighbouring country (statistics publish only county-level data on the citizenship data of international immigrants). The net migration balance of Croatia was $+66,682$ for the 2001-2011timeframe. Some $88.9 \%$ of the immigrants and emigrants were Croatian citizens. The greatest number of non-nationals had passports issued by Post-Yugoslav states (4\% of the immigrants and $2.6 \%$ of the emigrants had Bosnian passports). Up until the global economic crisis, the positive balance of international migration had been above 1.3 thousand (in 2003, all counties were net receivers). From 2008 on, this trend has reversed (between 2010 and 2012 emigration of one thousand had been measured). Considering a broader timeframe, from 1998 (restoration of sovereignty) up until 2008, the migration balance was $+163,443$ people: $93.5 \%$ of the 254,068 immigrants were Croatian, $2.5 \%$ Bosnian and $1.3 \%$ had SerbianMontenegrin citizenship. Of the 90,625 emigrants $79.7 \%$ were Croatian, $6.7 \%$ Bosnian, $3.4 \%$ Serbian-Montenegrin with $8.6 \%$ unknown. The 14,430 migration loss of Croatians between 2009 and 2012 was determined to a lower extent by regional trends (e.g. returning refugees). From the 45,376 emigrants $85.1 \%$ were Croatian, $4.3 \%$ Bosnian, $0.8 \%$ Serbian, $0.4 \%$ Macedonian and $4.6 \%$ unknown. In case of the 30,946 immigrants, the picture is more varied: $67 \%$ had Croatian, $11.3 \%$ Bosnian, 3.2\% Serbian, 
2\% Slovenian, 1.9\% German, 1.7\% Macedonian, 1.5\% Chinese, 1.1\% Italian and Russian passports. Between 2002 and 2011, three counties were net receivers in every year (Zadar, Varaždin and Zagreb). As a whole, the population of 13 counties was increased by international migration. Based on data per thousand people, we can say that the population in four Adriatic counties (Zadar, Dubrovnik, Split, Istria) increased annually on average by $2.7-4.4$ people per thousand, while this figure was $1.4-1.8$ in the other coastal counties and the capital city's region. The annual average was +0.3 in all four Northern counties. The +1.1 value in Slavonski Brod can be considered significant. From among the seven Slavonian donor counties, the losses of Osijek were the lowest $(-0.1)$, and the decline in Sisak the highest $(-2.4)$. Lika, considered a net sending county from 2005, was characterized by the most severe emigration (average -2.7 people); the trend reached its peak with -9.3 people in 2009 .

Table 2

Migration balance (per thousand people) in Croatian counties, 2002-2011

\begin{tabular}{l|r|r|r|r|r|r|r|r|r|r}
\hline \multicolumn{1}{c}{ County } & \multicolumn{1}{c|}{2002} & 2003 & \multicolumn{1}{c}{2004} & \multicolumn{1}{c}{2005} & 2006 & 2007 & 2008 & 2009 & 2010 & 2011 \\
\hline Bjelovar-Bilogora & -1.8 & -2.2 & -3.0 & -3.3 & -3.3 & -4.1 & -2.2 & -2.9 & -5.2 & -6.4 \\
Slavonski Brod-Posavina & -0.9 & -1.8 & -1.5 & -0.9 & -1.9 & -1.1 & -1.1 & -5.7 & -4.1 & -4.3 \\
Dubrovnik-Neretva & 2.7 & 2.1 & 4.4 & 4.0 & 4.3 & 4.1 & 5.8 & 3.9 & -1.7 & -1.3 \\
Osijek-Baranja & 0.0 & 0.1 & -1.3 & -1.9 & -2.6 & -3.3 & -1.0 & -1.8 & -2.0 & -1.8 \\
Istria & 7.7 & 8.5 & 7.0 & 6.8 & 6.8 & 6.4 & 6.5 & 3.2 & 0.4 & -0.4 \\
Koprivnica-Križevci & -0.4 & -0.7 & -0.2 & -0.6 & -1.4 & -0.2 & 0.3 & -0.8 & -0.9 & -1.3 \\
Karlovac & -2.3 & -0.5 & -0.2 & -1.5 & -2.6 & -1.9 & -1.7 & -5.3 & -4.0 & -4.5 \\
Krapina-Zagorje & -0.9 & 0.5 & 0.2 & 0.9 & -0.4 & -0.3 & 0.3 & 0.4 & -0.4 & -0.9 \\
Lika-Senj & 0.4 & 3.1 & 1.6 & -1.0 & -1.5 & -3.3 & -1.9 & -10.2 & -6.2 & -5.8 \\
Međimurje & 0.1 & 0.2 & -0.5 & -0.6 & -1.1 & -1.0 & -0.9 & -0.1 & -0.7 & -1.3 \\
Požega-Slavonia & -2.4 & -3.7 & -2.8 & -3.8 & -4.5 & -4.2 & -4.1 & -7.6 & -6.3 & -8.8 \\
Šibenik-Knin & 6.3 & 5.6 & 6.2 & 6.3 & 8.1 & 3.7 & 4.2 & -3.0 & -6.7 & -8.2 \\
Split-Dalmatia & 4.9 & 4.8 & 6.4 & 3.9 & 2.4 & 1.5 & 1.8 & 0.3 & -0.9 & 0.1 \\
Sisak-Moslavina & -1.2 & -1.6 & -1.7 & -3.5 & -4.0 & -6.6 & -5.5 & -8.9 & -7.8 & -9.0 \\
Primorje-Gorski kotar & 3.0 & 3.4 & 2.9 & 3.3 & 3.1 & 2.5 & 2.1 & 1.0 & 0.8 & 0.8 \\
Varaždin & -0.3 & -0.2 & -0.4 & 0.0 & -0.2 & 0.8 & 0.7 & 0.3 & -0.2 & 0.4 \\
Virovitica-Podravina & -1.5 & -2.1 & -7.1 & -3.2 & -4.9 & -4.6 & -2.5 & -8.3 & -5.1 & -3.8 \\
Vukovar-Srijem & -4.2 & -4.7 & -3.9 & -3.6 & -3.5 & -1.0 & -1.2 & -5.1 & -7.1 & -6.9 \\
Zadar & 9.3 & 9.9 & 10.6 & 11.5 & 12.1 & 9.4 & 8.3 & 4.3 & 3.8 & 4.4 \\
Zagreb & 10.0 & 10.6 & 8.5 & 8.2 & 6.9 & 6.5 & 5.6 & 4.0 & 2.7 & 2.7 \\
City of Zagreb & -0.1 & 3.5 & 3.9 & 1.4 & 2.8 & 3.1 & 3.0 & 2.7 & 1.7 & 2.7 \\
\hline & 1.8 & 2.6 & 2.5 & 1.7 & 1.5 & 1.3 & 1.6 & -0.3 & -1.1 & -1.0
\end{tabular}

Source: author's calculation based on the data of the Croatian Bureau of Statistics.

In the case of county level migration, during the research period, the main target areas were Zagreb county (15,510 people) and the capital city ( 8,154 people). Further beneficiaries of the internal migration were the Northern region of the Adriatic Sea $(15,374$ people) and with only 88 people, the mountain area (Lika). It is interesting that despite international migration trends, Split and Dubrovnik are net senders in the case of county-level migration $(-3,728$ people). The internal migration affects the Pannonian region the most: the four Northern counties lost approximately 3,000 people, and circa 35 thousand inhabitants have left the Slavonian counties over the last ten years. The 
ability to retain population was weakest in Vukovar and Slavonski Brod. Throughout the last 10 years, the 10 Pannonian counties have constantly been donor counties, while four counties (Zagreb, Zadar, Istria, Primorje županija) have played the role of receiver. The relative indicators exceeded 4 per thousand only in the case of Zagreb and Zadar counties; the capital city rate was +1.0 annually on average. It has to be noted, that Lika, showing the least favourable demographic features had a positive value. The number of emigrants per thousand people was 0.2-1.4 in case of the four Northern counties, as well as in Split, Dubrovnik, Karlovac and Osijek counties, while in the six Slavonian counties, it was 2.6-3.8 (Table 2).

From the aspect of age structure, macro-regional specificities can be to some extent traced. The weight of the young generation is reflected in the relative values of natural productivity; however, there are also exceptions, (e.g. Istria, capital city), which are mainly explained by the large scale migration of people of working age. In the long run, the population pyramid is determined by the fact that there are only two counties (Međimurje, Zagreb), where the number of people under 15 years of age exceeds that of people above 65 years of age. By 2011, the young-elderly proportion was $86 \%$ countrywide, which majorly shifts towards the seniors in case of mountain area territories. The nation-wide rate of people of working age and dependents is $203.7 \%$. Respective values of the capital city region, Istria county with a high GDP per capita level, the four Northern counties and the three regional centres, are better than 2:1, which is a result of the increased working opportunities. Dependency ratios are higher than this in the Slavonian counties and the Adriatic region, which can be characterized by a higher life expectancy.

\section{Ethnic developments}

Over recent decades, the proportion of people who consider themselves Croats has decreased in Croatia both in absolute and relative terms. At the time of the 1971-1991 censuses, the proportion of those of Croatian nationality was below $80 \%$, which increased to 89.63 after the war and continued rising to $90.42 \%$ by 2011 . This phenomenon was mainly due to the drastic drop in the Serbian population. There are eight populous nationalities in Croatia. The majority, the indigenous national minorities (Serbs, Italians, Hungarians, Slovenians and Czechs) can be characterized by a continually declining population due to various reasons: natural decline, assimilation and emigration. Three national minorities show an opposite trend: the number of Bosnians, Albanians and Roma not only increased because of the high fertility rate, but also as a consequence of immigration and weak assimilation. Based on their demographic specificities, the single minorities can be classified in clearly separated groups; their spatial location (despite their relatively small proportion) explains certain county level demographic specificities. Considering their average age, larger ethnic groups can be classified as follows: the Roma (21.9 years of age) and the Albanians (32.4 years) can be considered the youngest, while the oldest are the Slovenians (59.7 years), Serbians (53.1), Hungarians (50.7) and Italians (50.3). These features are reflected in the data of the population pyramid and the dependency indicators. The outstanding values of the 
working age population (75.8\% and 71.3\%), show that mainly Bosnians and Albanians of working age have moved to the country during the last two decades.

From among the counties in Istria, where regional identity's census affiliation has been favoured for a long time $(12.11 \%$ of the population of Istria county indicated in 2011 as well their regional identity), the proportion of Croatian nationals (68.33\%) is the lowest, while Krapina county is inhabited almost only by Croats $(98.84 \%)$. The proportion of Croats is $89.3 \%$ in towns (with extreme values varying in the interval $1.78-100.0 \%$ ), in cities the respective value is $90.1 \%$ (48.73-99.31\%), while in districts of the capital city, it is $93.14 \%(87.0-97.3 \%)$. There are only 22 towns and one small town (Buje, Istria) in Croatia, where the proportion of Croatian nationals is below $50 \%$. These are relatively small settlements; their average population is below 3,000 people. Mainly Serbians and in unique cases Italians, Hungarians and Czechs form the most populous ethnic groups. Considering the extreme values in the counties, the Serbian population of Vukovar, Lika, Sisak, Šibenik and Karlovac exceeds 10\% (the maximum is $15.5 \%$ ), while their proportion is below $1 \%$ in Varaždin, Međimurje županija, Krapina and Zagreb counties. The geographical situation of Bosnian, Albanian and Slovenian nationalities are explicitly dispersed. The Roma population lives mainly in Međimurje županija and the capital city, Hungarians in Osijek-Baranja županija, Czechs in Bjelovar county and Italians in Istria.

\section{Settlement network, urbanization}

The settlement network has reflected spatial consequences of natural, demographic, historic, social, economic and political developments at all times, while it is forming the basis for future efforts that can only hardly be changed in the short run (e.g. by planting new industrial or administrative funcions). The settlement network, as a system synthesizing the impacts of different factors, is relatively stable, and is mainly formed over the long term. However, certain elements (e.g. administrative system) can be modified by an individual decision (e.g. by the introduction of a new territorial administrative system). There were three groups of factors that affected the Croatian settlement network significantly, although, not to the same degree: the complex physical geographical environment, the "empire chaining space" character (state borders, frequent changes of power centres, continuous rearrangement of the core territory) and the ethniccultural specificities. By the time of Croatia's independence, from 1991, new, nation state-like developments were unfolded relating both to urban policy and urban development. These changes could be seen first in the capital city; later, cities and towns along the new state borders also had to face a new situation. The developments, after the breakup of Yugoslavia, have unfolded in an entirely different way and political framework than previously; the socio-spatial, economic, political, and development aspects were presented in a new manner. Consequently, we will examine the changes in the settlement network compared to the 1991 status quo.

When, in 1992, Croatia returned to its historical traditions, it brought 70 municipalities with city rights into its new administrative system. In 1995, the number of cities rocketed and the number of municipalities with city rights increased to 122 . Thus, the set of cities was established, and by 2011, it had grown to 127 (Figure 3). 


\section{Croatian cities in 2011}

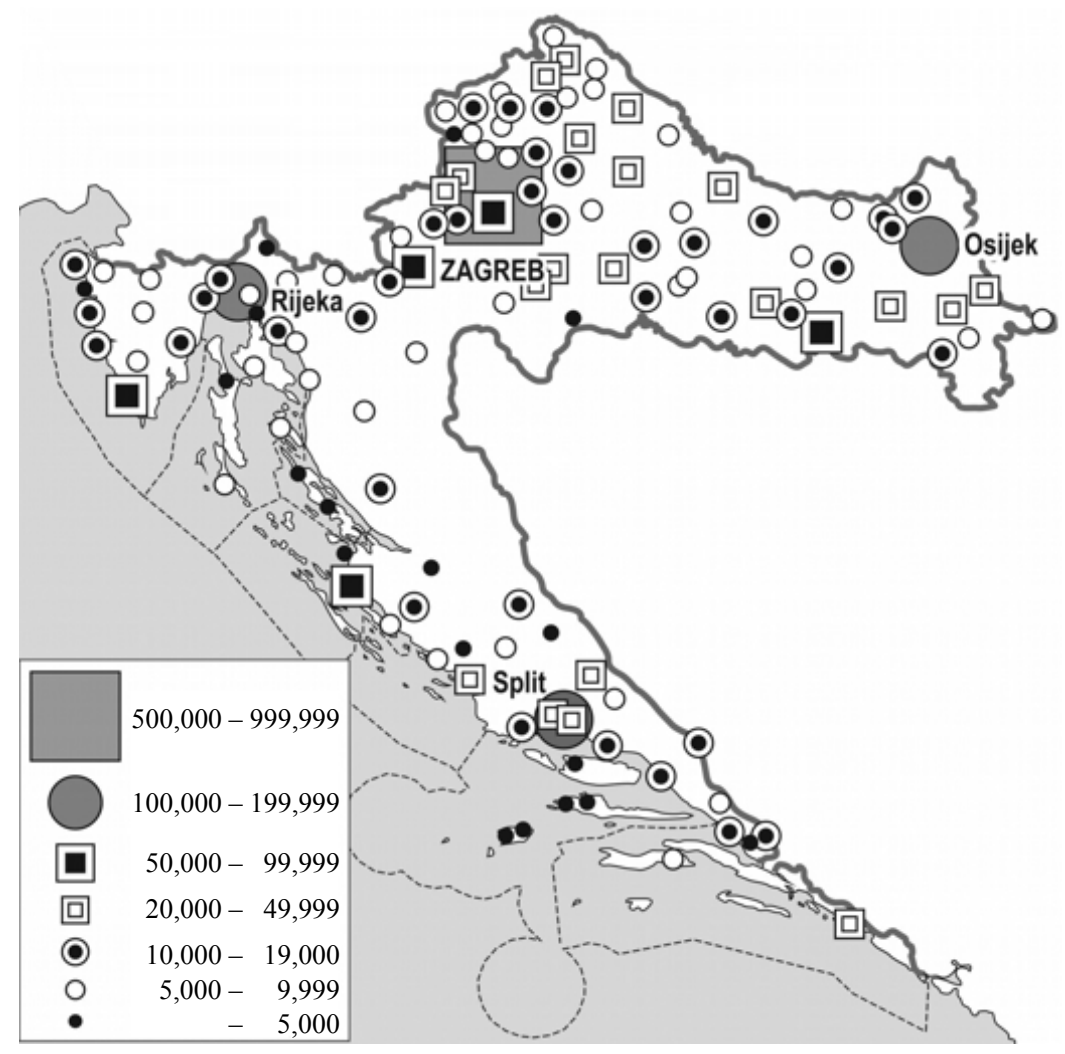

Source: author's compilation based on census data.

A specificity of the Croatian settlement network is the disparity of the population and the high number of small settlements (Strategija 1997). Around one third of the population lives in settlements below 1,000 people, however, as many people live in cities above 50 thousand. The proportion of the urban population is around $55 \%$ (the national statistics publish slightly lower, the UN statistics slightly higher data) and the trend is slowly increasing. From among the Western Balkan countries, Montenegro and Macedonia precede Croatia in this aspect; however, even their indicators are lower than the EU average. When studying the structure of the settlement network, initially it can be concluded that the number of settlements has barely changed over the last 20 years. The distribution of the population according to settlement size shows the following trend in the 1991-2011 timeframe. Depopulation is a characteristic feature of the Balkans including Croatia. The number of depopulated settlements continues to rise: while in 2001 there were 105 such settlements, 150 settlements $(2.22 \%$ of the total number of settlements) were uninhabited by 2011. The proportion and population of settlements under 100 people is increasing. This is one of the settlement sizes, which represents an 
opposite trend to the county level population decline. A parallel process is the weight loss of settlements between 100 and 1,000 people, both in relative and absolute terms, i.e. both their proportion in the urban network and their population are decreasing. The 2,653 settlements with a population below 100 are mainly located on the Istrian peninsula, the $30-80 \mathrm{~km}$ radius of the capital city, the Slavonian Mountains and in the islands and peninsulas of Kvarner and Central-Dalmatia. The 3,424 settlements between 100-1,000 people form the primary structure of the settlement network, meaning, that they are relatively evenly distributed across the country, with one-fourth of the population living in such settlements. According to national trends, the proportion of the settlement category s between 1,000 and 10,000 can be considered stable. The population of settlements between 1,000 and 5,000 has been declining. The group of settlements of $5-10$ thousand has barely changed over the last twenty years.

The number of settlements below 10 thousand (39) - with only one exception - has also not changed in the 1991-2011 timeframe. The population of settlements fulfilling the formal criteria of cities by themselves - in light of the national demographic features has been decreasing. Within the larger settlement categories (notwithstanding whether they are catagorised at 20,25 or 30 thousand inhabitants) there has been only a slight shift, due to the category change of 1 or 2 settlements. Zagreb, as a settlement (the capital city's local government integrates 70 settlements) provides home for an increasing proportion of the population. In 1991, Zagreb incorporated $14.77 \%$ of Croatia's population; twenty years later the respective value was $16.06 \%$. Despite the phenomena of natural population decline and suburbanization, this means that the population of "inner" Zagreb, in absolute terms has barely changed.

There are significant differences between the counties considering both the urban network and urban population. While, in Adriatic counties, we have 5-16 cities, in Slaviona, the number of cities per county varies between 2 and 7.

\section{Economic development}

Regional disparities can be considered normal in case of a country whose territorial features are as diverse as Croatia's. This versatility facilitating different income opportunities can be considered an asset from an economic viewpoint. Physical geographic features basically determine the spatial structure of an economy, however, this relationship is not always deterministic. Agriculture is the traditional field of activity in the Pannonian territories; whereas cities serve as industrial and service centres (the plain facilitates larger population concentrations). The service sector is dominant in the Adriatic region; the most important business branch is tourism (its weight is very considerable within the national economy). The principal port cities' significant activities are shipbuilding, fish processing and energetics, the role of agriculture is secondary. A specificity of the urban network is that the population (and business) is concentrated in two large cities on the coastline, while small villages are characteristic of the surrounding countryside and islands. Forestry, animal husbandry, and to a limited extent, industrial activities are most characteristic of the Dinaric mountains. The mountains are scarcely inhabited; they are in a demographically unfavourable situation: the settlement network is scarce and the population of towns does not reach ten thousand (Figure 4). 


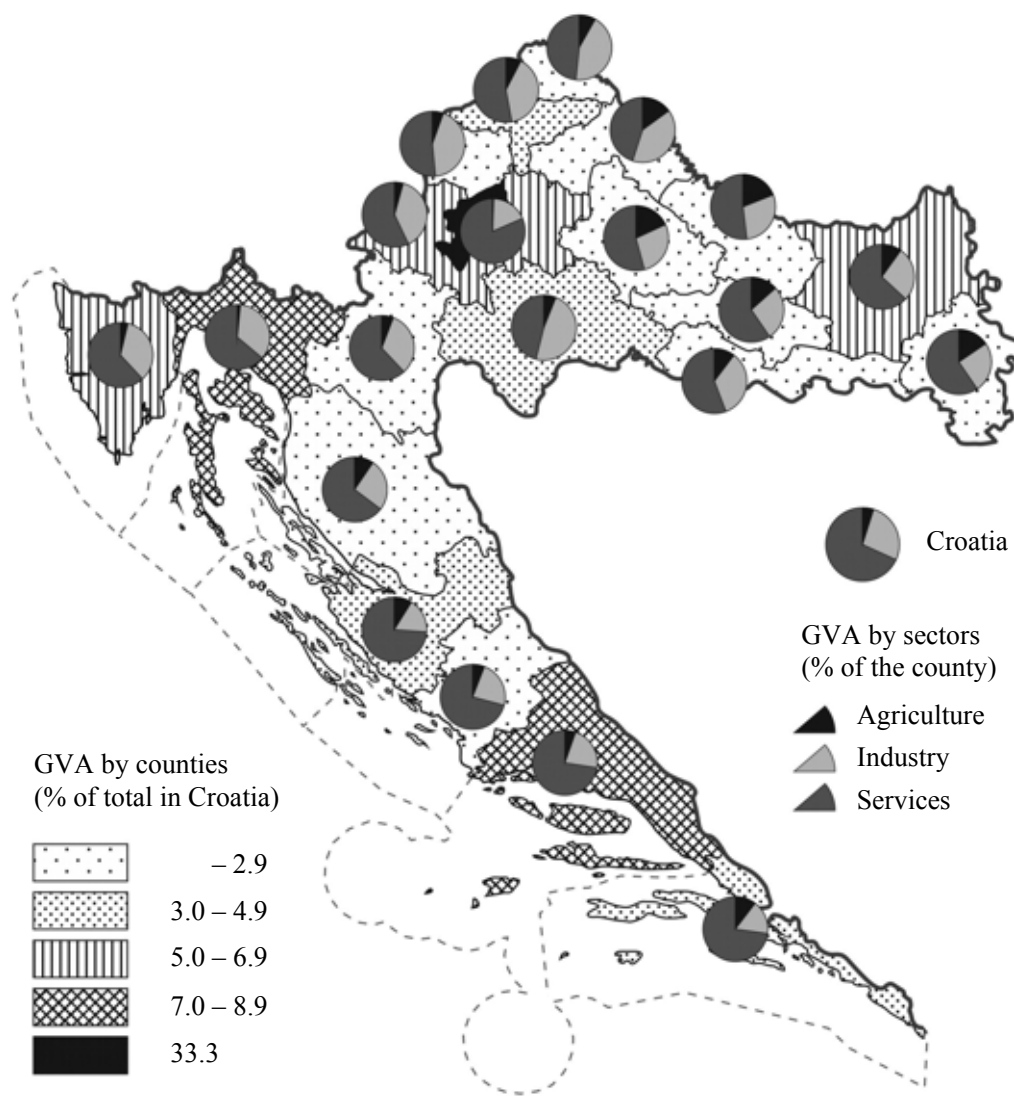

Source: author's compilation based on the data of the Croatian Bureau of Statistics.

Historical regional differences that were accentuated by the transition period (Sić 2003, Lovrinčević-Mikulić 2012) and the damage caused by the Balkan war were of different extent and character. The developments after the turn of millennium, the EuroAtlantic integration (Karaman Aksentijević-Ježić 2011, Koči-Pavlaković-Pejnović 2005, Puljiz-Maleković 2007, Škuflić et al. 2010), the increasing FDI inflows (Škuflić-Botrić 2009), and eventually the economic crisis were all factors that necessarily caused the deepening of (social and economic) development borderlines within the country that can be interpreted on several territorial levels.

Just as in other countries of the region, the economic controlling role and power of the capital city and its region are outstanding; they attract both population and business. Zagreb is the only metropolitan area in the country; it is an economic, intellectual and transport centre. The capital is Croatia's most important growth pole: $18 \%$ of the population, $19 \%$ of the employees, $25 \%$ of industrial output, $33 \%$ of GDP, $53 \%$ of university students and $67 \%$ of new investments are concentrated here. 
The three developed macro-regional centres - Split, Rijeka and Osijek - form the second line of the urban network; their features are different due to their geographic location. Split is one of the determining factors in Dalmatia's development (its contribution to GDP is $8.8 \%$ ) and there are several towns in its agglomeration. Its industrial capacities are significant; the development of tourism is beyond average. In its hinterland, Bosnia might be a potential link; it is also the city that provides the major part of the Croatian ferry service towards the Italian Ancona on the other side of the Adriatic Sea. Rijeka is the traditional centre of the nation's maritime economy (port industry, international freight transit). Its performance could be ameliorated significantly by the formation of a potential Serbian or Bosnian link; however, from a transport geographical perspective, its situation is less favourable than those of Trieste or Koper. This region is the leading tourist region in Croatia with its features well exploited. This is underlined by the fact that for decades - besides the capital city - only the GDP per capita of Istria and Primorje županija has exceeded the national average. The respective contribution of these counties to the GDP is 8.4 and $6.2 \%$. While the two large Adriatic cities open windows towards several regions of the world, Osijek is a window towards the Carpathian Basin. Onthe edge of the war, the economic and intellectual centre of Slavonia suffered severe damage. Following the geopolitical reorientation, the region become a periphery, and in its development lags behind (in 2010, 5.4\% of Croatia's GDP was produced here), especially in contrast to the capital city and the littoral cities that "reinvented" themselves (Faragó-Rácz 2011).

From the time of the millennium, Croatian territorial GDP data has been available. The NUTS2 level statistics cover significant internal differences, especially in case of continental Croatia, which is inhabited by almost 3 million people and includes the capital city (DZS 2012a, 2013b). Considering the trends, the GDP production of Zagreb is becoming increasingly more significant in a national context; at the turn of millennium it was $29.2 \%$, at the beginning of the crisis $31.4 \%$, while it reached $33.33 \%$ by 2010 . The Adriatic NUTS 2 region had been increasing its economic weight by a growth rate of annually $9 \%$ up until the time of the crisis; from the $31.1 \%$ of 2000 , it grew to $32.5 \%$ by 2007, and this level was also maintained after the drop. The areas of Zadar, Split, Šibenik and Dubrovnik played a catalyst role in GDP growth. From 2001 until the beginning of the crisis, Rijeka's growth reflected the national average, a phenomenon which was due to the city's relative underdevelopment; the other counties started their development from a substantially lower level. In the 2000-2008 period, the Pannonian counties - except for Osijek - had shown a GDP growth below the national average. The crisis augmented the development disadvantages; the drop back in the continental counties was $8-18 \%$ between 2008 and 2010 (except for Sisak). Considering the whole time period of 2000-2010, we can conclude that the GDP growth in the capital and the five Adriatic counties was above the national average, while Dubrovnik, Zadar, Šibenik counties and Zagreb doubled their gross product despite the crisis. From among the Pannonian counties, the performance of Zagreb was the highest; it was somewhat higher than in Međimurje županija and (Primorje županija). The nominal growth in the other continental counties (including Lika) was between 133.3 and $168.6 \%$. The Pannonian territory without the capital city had suffered severe damage within one decade, and the pace of development was lagging behind the Croatian average. The crisis hit this region harder than most, therefore its contribution to the Croatian GDP continued to decrease ( $2000-39.5 \%, 2010-34.1 \%)$. 
The GDP per capita throughout the last decade has more than doubled, with the growth in Zadar, Šibenik and Split above the national average. Compared to the national average, Zagreb has also increased its lead above this this indicator (despite the population growth): from $166.5 \%$ (2000) it has grown to $185.4 \%$ (2010). Dubrovnik can be considered the only convergence county that could keep up with the capital city; this is mainly due to the rapidly prospering Southern Dalmatian tourism. Slavonski Brod and Vukovar had been the poorest counties for years; they are lagging behind even after the post-war reconstruction, they barely exceed the half the Croatian GDP/capita or the $30 \%$ of the EU27. It is only the capital city that exceeds the average development level of the EU member states (Table 3).

The most competitive counties (Singer-Lenardić 2011) are the capital city, Zagreb, Varaždin, Međimurje županija and Istria. In a national context, Virovitica, Požega, Slavonski Brod, Vukovar, Sisak and Lika were uncompetitive before the crisis and in 2010. When considering the net average wages, the position of Varaždin and Međimurje županija are outstanding in the competitiveness ranking. The average salary is significantly higher in the coastal region than in the continental counties. Zagreb ameliorates the national average substantially; practically, the capital city is the only county where the average income exceeds the national level.

Table 3

Economic information on Croatian counties

\begin{tabular}{|c|c|c|c|c|c|c|}
\hline County & $\begin{array}{l}\text { Per capita } \\
\text { GDP, } \\
2000\end{array}$ & $\begin{array}{c}\text { Per capita } \\
\text { GDP, } \\
2010\end{array}$ & $\begin{array}{c}\text { Registered } \\
\text { unemploy- } \\
\text { ment rate, } \\
2011\end{array}$ & $\begin{array}{c}\text { Gross } \\
\text { investment } \\
\text { in fixed } \\
\text { assets, } \\
2011\end{array}$ & $\begin{array}{c}\text { Export, } \\
2011\end{array}$ & $\begin{array}{c}\text { Import, } \\
2011\end{array}$ \\
\hline Bjelovar-Bilogora & 75.0 & 66.8 & 150.8 & 0.8 & 1.0 & 0.7 \\
\hline Slavonski Brod-Posavina & 61.0 & 53.3 & 177.0 & 0.8 & 1.3 & 1.1 \\
\hline Dubrovnik-Neretva & 89.9 & 104.0 & 98.4 & 1.3 & 0.3 & 0.3 \\
\hline Osijek-Baranja & 77.9 & 75.0 & 149.2 & 5.4 & 4.9 & 2.6 \\
\hline Istria & 131.1 & 128.2 & 60.2 & 4.9 & 10.0 & 4.5 \\
\hline Koprivnica-Križevci & 101.7 & 80.4 & 97.9 & 1.0 & 2.6 & 1.1 \\
\hline Karlovac & 78.7 & 73.6 & 130.9 & 1.7 & 2.1 & 1.1 \\
\hline Krapina-Zagorje & 75.7 & 60.5 & 95.3 & 1.0 & 3.2 & 1.5 \\
\hline Lika-Senj & 83.9 & 82.3 & 116.8 & 0.4 & 0.1 & 0.1 \\
\hline Međimurje & 82.2 & 78.4 & 88.0 & 1.1 & 4.1 & 1.9 \\
\hline Požega-Slavonia & 72.9 & 60.2 & 137.2 & 0.5 & 1.0 & 0.4 \\
\hline Šibenik-Knin & 71.7 & 78.4 & 122.0 & 1.2 & 2.2 & 1.4 \\
\hline Split-Dalmatia & 79.3 & 80.3 & 125.7 & 4.7 & 6.3 & 3.8 \\
\hline Sisak-Moslavina & 94.1 & 83.1 & 161.8 & 1.1 & 5.6 & 1.8 \\
\hline Primorje-Gorski kotar & 129.4 & 122.7 & 82.2 & 5.9 & 6.1 & 4.7 \\
\hline Varaždin & 91.5 & 81.6 & 78.5 & 2.2 & 7.6 & 3.4 \\
\hline Virovitica-Podravina & 73.8 & 58.4 & 170.2 & 0.5 & 1.0 & 0.5 \\
\hline Vukovar-Srijem & 58.6 & 54.9 & 168.6 & 1.7 & 1.6 & 1.1 \\
\hline Zadar & 74.3 & 81.4 & 109.9 & 2.2 & 1.8 & 0.9 \\
\hline Zagreb & 79.6 & 71.2 & 94.2 & 3.5 & 3.1 & 7.7 \\
\hline City of Zagreb & 166.5 & 185.4 & 49.2 & 57.9 & 33.2 & 58.3 \\
\hline Croatia & 100.0 & 100.0 & 100.0 & 100.0 & 100.0 & 100.0 \\
\hline
\end{tabular}

Source: Croatian Bureau of Statistics. 


\section{Labour-market trends}

Yugoslavian labour had been characterized by a relatively higher proportion of professionals than in the other socialist countries, this applied to the major part of the population in the more developed member states. The percentage of high school and university graduates is continually increasing in Croatia. In 2011, the proportion of people with at least secondary education was 69\% (Babić et al. 2006). According to the statistics, the chance of getting a job is higher with a higher level of education both in Europe and Croatia. The level of employment - barely exceeding 50\% - is significantly lower than in other EU member states in the region, and currently it is the lowest in the EU28. As a consequence of the economic crisis, the employment rate, following a short catch up period at the time of the millennium, dropped back significantly. Some $38.7 \%$ of those with primary level education, $59.7 \%$ of secondary school graduates and $76.9 \%$ of tertiary education were employed in 2012. The employment rate of the age group 25-39, just like in the other European countries, exceeds the respective indicators of the 40-64 age group; in Croatia this difference is twice as high as the European average: this can be considered a kind of Central and Eastern European specificity.

Macro-regional specificities of education are shown by the fact that the education level in the continental counties (including Lika) is typically lower than in the coastal region. The capital's position is unique from this point of view: this is the only region, where the number of university graduates exceeds the number of people with maximum primary education; a phenomenon which reflects Zagreb's leading position and development potential. Regarding Ph.D. holders, $86 \%$ are concentrated in the regional centres, in the regions of the four university cities. The proportion of people with a doctoral degree in smaller university cities (Zadar, Dubrovnik, Pula) is also significant. The number of people without even primary education on a national level is 171 per ten thousand people. The respective data in the Slavonian counties are lower (Vukovar 348 people), as in certain Adriatic counties (Šibenik 397, Zadar 290, Lika 249, Split 198 people). The four Northern counties, the capital city's area and the more developed Adriatic counties form the other extreme (Zagreb 73, Istria 72, Primorje županija 67 people).

The impacts of the economic crisis can be clearly traced when looking at the development of the unemployment rate. The number of job seekers had been continuously decreasing until 2008; by 2009, Croatia approximated the EU average. However, by the $4^{\text {th }} 5^{\text {th }}$ year of the crisis, unemployment doubled. In contrast to the European average, the impacts of the crisis on Croatia were stronger and more continuous. Currently, only Spain and Greece precede Croatia regarding the unemployment rate. The situation is the same when considering the ranking by long-term unemployment and the unemployment of people below 25 years of age.

The county data show macro-regional co-movement, which is consistent with the education and economic development. Unemployment is highest in the seven Slavonian counties: it is around $130-180 \%$ of the Croatian average. The Capital and Istria are the most developed territories traditionally; the unemployment rate in these regions is half the national average. The indicators of the four Northern counties and Zagreb county (Central Croatia), are below the national average. Dispersal of the coastal counties' data 
is significant, besides Istria and Primorje županija, the indicators of Dubrovnik showed rather favourable developments, while the unemployment rate in Lika, Zadar, Šibenik and Split is continuously above the Croatian average. In contrast, the Slavonian counties lag behind these favourable developments. Those counties have been worst affected by the financial crisis, where the proportion of industries exposed to the world market (tourism, export-oriented activities) was higher, i.e. Zagreb and its region in a broader sense (Central Croatia), Istria and Primorje županija. There were only two counties where the increase in unemployment due to the crisis was not continuous; at this time, there are no signs of long-lasting recovery. Presumably, a lasting decrease in the unemployment rate will only follow in the most developed regions.

\section{Development of priority sectors}

Croatia developed its highway network with unprecedented speed throughout the last decade $(1998-330 \mathrm{~km}, 2009-1244 \mathrm{~km})$, in order to strengthen both its tourist and transit potential, and its internal cohesion (the passenger transport "modal split" in passenger kilometres: $85.4 \%$ car, $9 \%$ bus/trolleybus, $5.6 \%$ train). The network is Zagrab focused; however, it facilitates fast transportation around the whole country. The Adriatic A1 highway - which currently ends by Ploče - has already had some visible results: both tourist arrivals and the value of real estate has increased in Dalmatia (Sić 2009). The Adriatic Highway's layout helped to open up several peripheral areas, for example, the scarcely inhabited županija of Lika, and in addition, it provided connections to the national network for the coastal resorts of Zadar and Šibenik, so they could improve their positions in the national ranking. From among the transport modes - due to the country's location - maritime and coastal water transport can be considered relatively healthy. Goods traffic in tons transported is concentrated in the following ports: Omišalj, Split, Rijeka, Ploče, Bakar. In 2011, the ports with the highest traffic were Split, Dubrovnik and Zadar. Due to the post war tourist conjuncture, air passenger traffic doubled between 2001 and 2008, then, after a brief drop, it has stabilized around 5-6 million passengers; one fifth of the flights are domestic. In 2011, the airports with the highest passenger traffic were Zagreb (2.2 million people), Dubrovnik and Split (1.3 million people). The above quarter-million passenger traffic of Pula and Zadar is also significant (DZS $2012 \mathrm{~b}$ ). The proportion of low-cost flights is noteworthy in the coastal towns. Tourism has been a traditional key area of Croatia's national economy. Throughout recent years, according to the satellite accounts of tourism, this industry has provided nearly one fourth of the GDP and employs $27-29 \%$ of all employees. Although the country's features are very diverse (national parks, cultural heritage sites, medicinal waters), tourism is still concentrated in the Adriatic region (95\% of the overnight stays). Tourism in Central Croatia is linked to the capital city.

Croatia, after the internal political turnaround, trod the path to Euro-Atlantic integration only after the turn of millennium. Consequently, foreign investments showed a significant lag in comparison to Slovenia and the Visegrád countries. Both war reconstructions and competitiveness investments were facilitated by the newly opened support opportunities. Nine- tenths of Croatia's foreign trade is carried out with European countries. Traditionally, the main foreign trade partners of Croatia are Italy, Germany, 
Slovenia, Austria, Bosnia-Herzegovina and Hungary. Considering imports, Russia and China are the most important players. A continuous problem of Croatian foreign trade is the significant deficit; the value of imports is more than double that of exports. The export weakness is due to the omitted and belated investments, the relative lack of capital and the (overvalued) exchange rate of the Kuna. The foreign trade balance is only positive in two product groups - beverages and tobacco, and crude materials except fuels. Similarly in the case of services, (mainly travel, transport and business services. The foreign trade deficit is the highest in the high value added industries, apart from some successful sectors (Lux 2013). This is also supported by the county level export trade data. The most significant corporations operate with Zagreb headquarters (one third of all active companies were registered with capital city head office), the Capital "produces" more than nine tenths of the foreign trade deficit. Only counties of some successful industrial centres (Sisak - petrol chemistry, Istria - ship building, tourism, Varaždin light and food industry) can ameliorate the trade balance to a significant extent.

\section{Conclusion}

Croatia, despite its relatively small territory, is composed of counties that can be characterized by striking differences. This is mainly due to the country's unique geographic location and the particular shape of the state territory. The state territory integrates regions, whose relations are different in many aspects and which partly overlap. The natural, social and historical factors' space forming effect is relatively high; although, there is no one determining spatial shaping effect. However, certain regional differences can be considered normal in the case of Croatia. The historical differences have been accentuated during the transition period (state forming, Balkan war). The developments after the turn of millennium, the Euro-Atlantic integration, the increasing FDI inflows, and eventually the economic crisis were all factors that inevitably caused the deepening of development (social, economic etc.) borderlines within the country that can be interpreted on several territorial levels.

This study reviewed the most important factors, based on which it can be determined whether individual counties and cities were winners or losers of the different social and economic developments of the last decade. On a macro-regional level, we can conclude that Croatian development has undergone a partial orientation shift, this has led to the coastal territories and the capital city region forging ahead, while the Eastern part of the country, Slavonia, has benefited least from the regional processes. Just like the neighbouring Post-Yugoslav and Central European countries, the role and development of the capital city is becoming increasingly more dominant.

This research could be further developed by an examination of the "new era". This time frame is characterized by European Union membership, as well as by the post World economic crisis situation. It is a question as to how individual, corporate and interstate relations will be shaped within the framework of protectionism (nationalism) and European territorial cooperation. What are the consequences of the different responses to the challenges? The in-depth examination of trans-border cooperation might provide an answer to the question that on what level and to what extent did territorial relations start to reorganize. In the 2007-2013 programming period, Croatian trans-border cooperation 
with EU members represented more than $85 \%$ of the CBC programmes. Strengthening of the bilateral programs with non-EU members was constrained by a number of factors (EU integration and institutional circumstances, socio-economic potential, mistrust), and raises the question regarding the possible timeframe for further significant changes.

\section{REFERENCES}

Babić, Z.-Matković, T.-Šošić, V. (2006): Structural Changes in Tertiary Education and Impacts on the Labor Market Croatian Economic Survey 9: 125-165.

Faragó, L.- Rácz, Sz. (2011): Urban network In: Horváth, Gy.-Hajdú, Z. (eds.): Regional Transformation Processes in the Western Balkan Countries pp. 256-288. Centre for Regional Studies of the Hungarian Academy of Sciences, Pécs.

Karaman Aksentijević, N.- Ježić, Z. (2011): Tendencies of development inequalities of Croatian counties Proceedings of Rijeka Faculty of Economics, Journal of Economics and Business 29 (2): 269-290

Klemenčić, M. (1994): Croatia - past and present: Location, position, territory, borders, regions Lurralde 17: 243-258.

Koči-Pavlaković, V.-Pejnović, D. (2005): Polarization of Regional Economic Development in Croatia - Trends and Challenges in a New Geographic Reality Hrvatski Geografski Glasnik 67 (2): 5-19.

Lovrinčević, Ž.-Mikulić, D. (2012): Croatia - Regional development and social indicators in Croatia World Bank, Washington DC.

Lux, G. (2013): Industrial restructuring in Central and South-Eastern Europe: difference of degree or kind? In: Pálné Kovács, I.-Scott, J.-Gál, Z. (eds.): Territorial cohesion in Europe pp. 375-388., IRS CERS HAS., Pécs.

Magaš, D. (2003): Contemporary aspects of the geographical regionalization and administrative-territorial organization of Croatia Geoadria 8 (1): 127-147.

Magaš, D. (2011): The Concept of Territorial Organisation of Adriatic Croatia Geoadria 16 (2): 211-236.

Mežnarić, S.-Stubbs, P. (2012): Social Impact of Emigration and Rural-Urban Migration in Central and Eastern Europe. Croatia. Final Country Report. European Commission. DG Employment. Social Affairs and Inclusion, Bruxelles.

Pavić, R. (2008): Contributions for supplement and modification in regionalization of the Republic of Croatia Geoadria 13 (1): 19-40.

Puljiz, J.-Maleković, S. (2007): Regional Income and Unemployment Disparities in Croatia In: Fredotović, M.Reić, Z. (eds.): Proceedings of the 7th International Conference on Enterprise in Transition. Faculty of Economics, Split-Bol.

Rogić, V. (1962): Fizionomska i funkcionalna regionalizacija Hrvatske. Zbornik VI. kongresa geografov., FLRJ, Ljubljana.

Rogić, V. (1973): Regionalizacija Jugoslavije Geografski Glasnik 35 (1): 13-29.

Rogić, V. (1983): Nacrt uvjetno-homogene regionalizacije SR Hrvatske Geografski Glasnik. 45 (1): 75-89.

Roglić, J. (1955): Prilog regionalnoj podjeli Jugoslavije Geografski Glasnik 16-17 (1): 9-20.

Sić, M. (2003): Regional disparities in Croatia Hrvatski Geografski Glasnik 65 (2): 5-28.

Sić, M. (2009): Utjecaj autoceste Zagreb-Split na regionalni razvoj Like Hrvatski Geografski Glasnik 71 (1): 87-101.

Singer, S.-Lenardić, M. (2011): Regional Competitiveness Index of Croatia 2010 National Competitiveness Council, UNDP Croatia, Zagreb.

Škuflić, L.-Botrić, V. (2009): Foreign direct investments in Croatia: regional perspective Ekonomska istraživanja 22 (3): 9-28.

Škuflić, L.-Rabar, D.- Šokčević, S. (2010): Assessment of the efficiency of Croatian counties using data envelopment analysis Ekonomska istraživanja 23 (2): 88-101.

Strategija (1997): Strategija prostornog uređenja Republike Hrvatske. Ministarstvo prostornog uređenja, graditeljstva i stanovanja, Zagreb.

Vresk, M. (1995): Regionalna struktura Hrvatske. Socioekonomske osnove strukturiranja Geografski Glasnik 57 (1): 55-70. 


\section{Statistical sources}

DZS (2001): Census of Population, Households and Dwellings, 2001 Croatian Bureau of Statistics, Zagreb.

DZS (2003-2012) (different years): Statistical Yearbook Croatian Bureau of Statistics, Zagreb.

DZS (2005-2013) (different years): Statistical information Croatian Bureau of Statistics, Zagreb.

DZS (2011a): Census of Population, Households and Dwellings 2011, First Results by Settlements Croatian Bureau of Statistics, Zagreb.

DZS (2011b): Population projections of the Republic of Croatia, 2010-2061 Croatian Bureau of Statistics, Zagreb.

DZS (2012a): Gross Domestic Product for Republic of Croatia, Statistical Regions at level 2 and Counties, 2009 (First Releases 12.1.3.), Croatian Bureau of Statistics, Zagreb.

DZS (2012b): Transport and Communication, 2011 (Statistical Reports 1465/2012.) Croatian Bureau of Statistics, Zagreb.

DZS (2013a): Census of Population, Households and Dwellings 2011, Population by Sex and Age Croatian Bureau of Statistics, Zagreb.

DZS (2013b): Gross Fixed Capital Formation (Gross Investment), 2011 (Statistical Reports 1507/2013.) Croatian Bureau of Statistics, Zagreb. 